KS. TOMASZ ROZKRUT

Wydział Prawa Kanonicznego

Uniwersytetu Papieskiego Jana Pawła II w Krakowie

ORCID 0000-0002-6189-5552

\title{
WŁAŚCIWE ZASTOSOWANIE „PROCESU BISKUPIEGO" W ORZECZENIU NIEWAŻNOŚCI MAŁŻEŃSTWA
}

Treść: Wstęp. - 1. Wybrane założenia reformy procesowej papieża Franciszka z 2015 roku. - 2. Procesowe zadania oraz obowiązki biskupa diecezjalnego. - 3. Wybrane praktyczne uwagi do "procesu biskupiego”. 4. Dynamiczny aspekt „procesu biskupiego”. - Zakończenie.

\section{Wstęp}

Minęło już kilka lat od nowelizacji przez papieża Franciszka w roku 2015 sposobu orzekania nieważności małżeństwa przez sądy Kościoła. Miniony czas, w szczególności nabyte w nim doświadczenia, zachęcają do postawienia ważnego pytania dotyczącego poprawności stosowania wprowadzonej, niewątpliwie odważnej, nowelizacji w prawie procesowym, w szczególności pytanie to winno dotyczyć „procesu skróconego”, gdyż mamy w tym wypadku do czynienia z nowym sposobem orzekania nieważności małżeństwa przez autorytet Kościoła. Konkretnie chodzi o „proces małżeński skrócony przed biskupem", o którym w nowych kan. 1683-1687, a który ze względu na swoją specyfikę może być też określany jako „proces biskupi”.

Czas pandemii spowodował znikome kontakty naukowe, oraz praktycznie uniemożliwił dyskusje i wymianę doświadczeń podczas sympozjów naukowych, które pozwalały w przeszłości na stawienie konkretnych pytań, ukazywanie powstałych problemów oraz 
sposobów ich właściwego rozwiązywanie. Należy mieć jednak nadzieję, że czas ten nie wpłynął negatywnie na orzecznictwo kościelne, przede wszystkim, w przedmiocie merytoryczności wydawanych orzeczeń.

Ważnym motywem do podjęcia tematu dotyczącego poprawnego zastosowania procesu skróconego przed biskupem jest artykuł, który opublikował G.P. Montini, a który dotyczy niezgodnego z prawem zastosowania processus brevior ${ }^{1}$. W szczególności cytowany włoski kanonista zwrócił uwagę na fakt, że dokonana przez Najwyższy Trybunał Sygnatury Apostolskiej analiza wyroku wydanego we Włoszech właśnie w processus brevior, który sukcesywnie został przesłany do Trybunału Apostolskiego celem uzyskania dekretu o jego wykonalności, aby z kolei wyrok kościelny na mocy obowiązującej umowy mógł zostać uznany przez władze cywilne, nie wykazuje istotnego elementu dla tego procesu, o którym stanowi nowy kan. 1683, n 2, a który określa, że „przytaczane są okoliczności dotyczące faktów lub osób, poparte zeznaniami lub dokumentami, które nie wymagają przeprowadzenia dokładniejszego badania albo dochodzenia oraz w sposób oczywisty wskazują na nieważność". Norma ta jasno ustaliła, że rekwizyt oczywistej nieważności małżeństwa jest konieczny nie tylko na początku procesu, ale musi być obecny w całym postępowaniu dowodowym, które ma doprowadzić do wyroku pozytywnego, aby nie można było postawić zarzutu, że processus brevior został nielegalnie przeprowadzony ${ }^{2}$. Wspomniana oczywista nieważność zaskarżonego małżeństwa winna się jasno demonstrować nie tylko na początku takiego procesu, ale także winna zostać bez trudności potwierdzona na etapie dowodowym, oraz w uzasadnieniu wydanego wyroku (na zasadzie triady istotnej dla "procesu biskupiego": evidenza-conferma-giudizio) ${ }^{3}$.

\footnotetext{
${ }^{1}$ G.P. Montini, L'uso illegittimo del processus brevior. Rimedi processuali ordinari e straordinari, Periodica 108 (2019), s. 35-72.

${ }^{2}$ Tamże, s. 57.

${ }^{3}$ Tamże.
} 
G.P. Montini wyraźnie wskazał, że instrukcja procesowa in casu nie wykazała oczywistych elementów wskazujących na nieważność zaskarżonego małżeństwa $\mathrm{z}$ zaproponowanego tytułu nieważności, co ewidentnie obarcza odpowiedzialnością, przede wszystkim, oficjała oraz instruktora; jak również i biskupa, który wydał wyrok pozytywny.

Konkretnie, pierwszy z nich niewłaściwie ocenił tzw. oczywistość nieważności małżeństwa i zbyt pochopnie wyznaczył proces biskupi. Jego obowiązkiem - zgodnie z kan. $1676 \$ 2$ - jest „zdecydować, czy sprawa ma być rozpoznawana w procesie zwykłym, czy w procesie skróconym, według kan. 1683-1687”. Z kolei instruktor - który powinien mieć świadomość, że zgromadzony materiał dowodowy - tej oczywistości nie wykazał, nie powinien sprawy kierować do orzekającego biskupa ${ }^{4}$.

Także delikatnym problemem procesowym jest nabycie przez wyrokującego biskupa pewności moralnej, koniecznej dla orzeczenia nieważności zaskarżonego małżeństwa. Papież Franciszek w kan. 1687 $\$ 1$ postanowił bardzo precyzyjnie: „po otrzymaniu akt biskup diecezjalny, po konsultacji z instruktorem oraz asesorem, rozważywszy uwagi obrońcy węzła i wnioski obrończe stron, gdy takie zgłoszono, jeżeli osiągnął moralną pewność co do nieważności małżeństwa, winien wydać wyrok. W przeciwnym razie przekazuje sprawę do procesu zwykłego"5. Kolejną, niewątpliwie także ważną kwestią, jest zachowanie się obrońcy węzła małżeńskiego, który powinien złożyć przynajmniej apelację od wyroku biskupa, zgodnie z nowym kan. 1687 $\$ 3$; wcześniej natomiast, jeszcze przed wydaniem pozytywnego orzeczenia, powinien przedstawić wyrokującemu biskupowi swoje uwagi w przedmiocie niewystarczalności zgromadzonego materiału dowodowego, który miałby być podstawą do pozytywnego wyrokowania.

\footnotetext{
${ }^{4}$ Tamże, s. 35n, przypis nr 1 .

${ }^{5}$ Zob. uwagi G.P. Montiniego na temat konieczności uzyskania przez wyrokującego biskupa pewności moralnej, w szczególności w przedmiocie ścisłej relacji między pewnością moralną a zastosowaną procedurą - tamże s. 47-49.
} 
Wskazane elementy wyłowione z praktyki sądowej, podpowiadają, aby syntetycznie przypomnieć to, co jest najbardziej istotne dla analizowanego sposobu orzekania nieważności małżeństwa przez autorytet Kościoła, tym bardziej iż Najwyższy Trybunał Sygnatury Apostolskiej, w sprawowanej funkcji kontrolnej nad kościelnym sądownictwem, nie zapomina o swoim duszpasterskim wymiarze pracy $^{6}$. Ten wymiar był niewątpliwie jednym z głównych motywów reformy procesowej papieża Franciszka.

\section{Wybrane założenia reformy procesowej papieża Franciszka z 2015 roku}

Analizując założenia reformy procesowej z roku 2015, dotyczącej nowelizacji kanonów Kodeksu prawa kanonicznego z 1983 roku w przedmiocie orzekania przez Kościół nieważności małżeństwa, należy przede wszystkim pamiętać o prawie Bożym, jego niezmienności oraz fundamentalnym znaczeniu, kiedy aplikujemy prawo kanoniczne do poszczególnych przypadków procesowych ${ }^{7}$. W szczególności należy mieć tutaj na uwadze istotne przymioty małżeństwa, czyli jedność i nierozerwalność instytucji, jak również sakramentalność małżeństwa ${ }^{8}$. Stąd też papież Franciszek napisał: „przeprowadziłem tę reformę, idąc za przykładem moich Poprzedników, którzy chcieli, aby sprawy o nieważność małżeństwa były rozpatrywane na drodze sądowej, a nie administracyjnej nie dlatego, że wymaga tego natura rzeczy, ale przede wszystkim dlatego, że wymaga tego konieczność

${ }^{6}$ D. Mamberti, Le molteplici competenze del Supremo Tribunale della Segnatura Apostolica in favore della giustizia nella Chiesa, w: Ius et matrimonium III. Temi di diritto matrimoniale e processuale canonico, red. H. Franceschi i M.A. Ortiz, Roma 2020, s. 23.

${ }^{7}$ Zob. T. Rozkrut, Studium i studia prawa kanonicznego w służbie reform papieża Franciszka, Annales Canonici 15 (2019) nr 2, 61-80.

${ }^{8}$ Zob. C.J. Errázuriz M., La problematica giuridico-canonica sul matrimonio e sulla famiglia nell'orizzonte della giustizia e della misericordia, Ius Ecclesiae 29 (2017), s. 553. 
zagwarantowania w najwyższym stopniu ochrony prawdy świętego węzła, a to właśnie zabezpieczają gwarancje porządku sądowego"

Ponadto papież Franciszek wskazał: „oprócz troski o bliskość sędziego, Konferencje Biskupów winny, z zachowaniem sprawiedliwego i godnego wynagrodzenia pracowników sądów, w miarę możliwości zadbać, aby proces był bezpłatny, gdyż Kościól, ukazując się wiernym jako szczodra matka w kwestii tak blisko związanej ze zbawieniem dusz, wyraża bezinteresowną miłość Chrystusa, dzięki której wszyscy zostaliśmy zbawieni"10. W przywołanej wypowiedzi należy w szczególności podkreślić troskę papieża Franciszka o łatwy dostęp do sprawiedliwości kościelnej, a mówiąc inaczej, o łatwy dostęp do sędziego kościelnego, dla osób które pragną rozwiązać w sposób ostateczny sprawy swojego sumienia na forum sądu kościelnego. Ten wymiar sądownictwa kościelnego, stał się praktycznie ważny w czasie ogólnoświatowej pandemii, która w żadnym wypadku nie może utrudniać rozwiązywania problemów ludzkich sumień oraz dotarcia do sędziego kościelnego.

Praktycznym wyrazem tej troski Biskupa Rzymskiego jest nowy kanon procesowy, kan. 1672, określający w sposób bardziej uproszczony oraz przystępny sądy kościelne właściwe w sprawach o nieważność małżeństwa. Oznacza to także, że wierny poszukujący sprawiedliwości będzie miał łatwiejszy dostęp do merytorycznie kompetentnego oraz dobrze przygotowanego do pełnienia takiej posługi sędziego kościelnego, który winien pamiętać o ciągłym swoim rozwoju intelektualnym. Widać zatem bardzo jasno jak reforma

\footnotetext{
${ }^{9}$ Papież Franciszek, List apostolski motu proprio „Mitis Iudex Dominus Iesus”, reformujący kanony Kodeksu Prawa Kanonicznego dotyczące spraw o orzeczenie nieważności małżeństwa, AAS 107(2015) s. 958-970. List apostolski motu proprio „Mitis et misericors Iesus", reformujący kanony Kodeksu Kanonów Kościołów Wschodnich dotyczące spraw o orzeczenie nieważności małżeństwa (tekst łacińsko-polski), Tarnów 2015 , s. 11 .

${ }^{10}$ Tamże, s. 15; zob. T. Rozkrut, Odpowiedzialność biskupa diecezjalnego, metropolity oraz konferencji biskupów za współczesny proces małżeński, w: Proces małżeński według motu proprio Mitis Iudex Dominus Iesus, red. J. Krajczyński, Płock 2015, s. 37-52.
} 
procesowa powiązana jest $\mathrm{z}$ troską o właściwy poziom studiów oraz studium prawa kanonicznego. Czas pandemii, który nie pozwolił na naukowe kontakty winien jednak zachęcać do indywidualnego studium prawa kanonicznego.

W Zasadach proceduralnych w sprawach o stwierdzenie nieważności małżeństwa czytamy: „To dochodzenie [chodzi tutaj o badanie przedprocesowe, czyli duszpasterskie, które odbywa się w strukturach parafialnych lub diecezjalnych] winno zostać powierzone osobom uznanym za odpowiednie przez ordynariusza miejsca, posiadającym kompetencje, nawet niekoniecznie prawnokanoniczne. Wśród nich winien być przede wszystkim proboszcz własny lub osoba, która przygotowywała małżonków do zawarcia małżeństwa. To zadanie doradcze może zostać powierzone również innym duchownym, osobom konsekrowanym lub świeckim zatwierdzonym przez ordynariusza miejsca"11. Bardzo konkretną odpowiedź na powyższy postulat znajdujemy w Instrukcji Kongregacji Wychowania Katolickiego z roku 2018, w szczególności w jej części na temat osób zaangażowanych we wprowadzenie bieżącej reformy prawa procesowego ${ }^{12}$.

Mówiąc bardzo syntetycznie trzeba podkreślić, że ta niewątpliwie bardzo znacząca i odważna reforma procesowa papieża Franciszka, ma służyć przede wszystkim zbawieniu dusz, o czym wielokrotnie czytamy we wstępie do m.p. „Mitis Iudex Dominus Iesus”; przy czym należy zawsze pamiętać, że każdy proces małżeński jest procesem „pro rei veritate" i od powyższej zasady nie może być żadnego odstępstwa ${ }^{13}$. Proces ten nie może także być w sposób nieuzasadniony upraszczany lub praktycznie „partykularnie” interpretowany niezgodnie z myślą Biskupa Rzymskiego. W tak nakreślonym kontekście wypada zgodzić

\footnotetext{
${ }^{11}$ Papież Franciszek, dz. cyt., s. 35, 37.

${ }^{12}$ Zob. Congregazione per l'Educazione Cattolica (degli Istituti di Studi), Istruzione, Gli studi di Diritto Canonico alla luce della riforma del processo matrimoniale, Presentazione di M.J. Arroba Conde, Lateran University Press, Città del Vaticano 2018.

${ }^{13}$ Zob. F. Coccopalmerio, Processo matrimoniale e missione della Chiesa, w: La riforma del processo matrimoniale ad un anno dal Motu Proprio Mitis Iudex Dominus Iesus, red. L. Musso i C. Fusco, Libreria Editrice Vaticana 2017, s. 13 i 18.
} 
się z uwagą, że dokonując licznych kościelnych reform papież Franciszek z odwagą zmienia to, co było już od lat postulowane i sugerowane $^{14}$. Naturalnie w tym skomplikowanym procesie reform punktem centralnym pozostają zawsze osoby w nie zaangażowane oraz za nie odpowiedzialne. Stąd też potrzebni są dzisiejszemu Kościołowi kanoniści odnowieni w wyniku poważnej formacji naukowej ${ }^{15}$.

Syntetycznie, wskazane założenia przypominają także niezmienne fundamenty reformy procesowej papieża Franciszka, których w żadnym wypadku nie można pomijać w codziennej wielowymiarowej pracy sądownictwa kościelnego.

\section{Procesowe zadania oraz obowiązki biskupa diecezjalnego}

Analizując wstęp do Listu apostolskiego motu proprio „Mitis Iudex Dominus Iesus", poprzedzający nowe kanony procesowe, natrafiamy w nim na dość liczne praktyczne wskazania, znacząco ukazujące nowe zadania spoczywające na biskupie diecezjalnym w przedmiocie reformy kanonicznego procesu małżeńskiego ${ }^{16}$.

Uwypuklić trzeba, że papież Franciszek na samym początku przypomniał doktrynę Soboru Watykańskiego II - która została także przypomniana w kontekście bardzo wymownej reformy prawa karnego w roku 2021 w Konstytucji apostolskiej „Pascite gregem Dei” a która jasno stanowi o tym, że to na biskupach spoczywa obowiązek sądzenia wiernych. W Konstytucji dogmatycznej o Kościele „Lumen gentium” czytamy: „na mocy tej władzy biskupi mają święte prawo i obowiązek wobec Pana stanowienia praw dla tych, którzy zostali powierzeni ich władzy, sprawowania sądów i kierowania wszystkim, co należy do dziedziny kultu oraz apostolatu"17.

${ }^{14}$ J.I. Arrieta Ochoa De Chinchetru, L'esercizio della funzione ecclesiastica nelle riforme di papa Francesco, w: I soggetti del nuovo processo matrimoniale canonico, red. C. Fusco i G. Moscariello, Libreria Editrice Vaticana 2018, s. 14.

${ }^{15}$ Zob. Tamże, s. 15.

${ }^{16}$ Zob. T. Rozkrut, Odpowiedzialność biskupa diecezjalnego, metropolity oraz konferencji biskupów za współczesny proces małżeński, w: Proces małżeński według motu proprio Mitis Iudex Dominus Iesus, red. J. Krajczyński, Płock 2015, s. 37-52.

${ }^{17} \mathrm{LG}, 27$. 
Konkretnie zatem w dzisiejszym Kościele biskup jest jednoosobowym sędzią $\mathrm{w}$ procesie skróconym ${ }^{18}$; ponadto to właśnie on ma zapewnić gwarancje rzetelności takiemu procesowi oraz zagwarantować ochronę instytucji małżeństwa: „istotnie, oprócz usprawnienia zwyczajnego procesu małżeńskiego, została ustanowiona forma procesu skróconego - oprócz obecnie obowiązującego procesu opartego na dokumentach - do zastosowania w przypadkach, w których skarga o nieważność małżeństwa jest poparta szczególnie oczywistymi argumentami. Nie umknęło jednak mojej uwadze, jak bardzo postępowanie skrócone może zagrozić zasadzie nierozerwalności małżeństwa. Właśnie z tego powodu postanawiam, aby w takim procesie sędzią był ustanowiony osobiście biskup, który mocą swego zadania pasterskiego daje największą gwarancję katolickiej jedności z Piotrem w wierze i dyscyplinie"19.

Równocześnie biskup ma być animatorem odnowy sądowniczych struktur Kościoła mu powierzonego, czyli na nim spoczywa ostateczna odpowiedzialność za funkcjonowanie sądownictwa kościelnego na poziomie pierwszej instancji. Konkretnie „biskup osobiście da sygnał do odnowy struktur kościelnych, oraz że nie pozostawi on całkowicie funkcji sądowniczej w sprawach małżeńskich urzędom kurialnym. Powinno się to odnosić szczególnie do procesu skróconego, który zostaje ustanowiony w celu rozpatrzenia spraw, w których istnieją najbardziej ewidentne przesłanki nieważności”20.

Natomiast z treści nowych kanonów procesowych wynika jasno, że w każdej diecezji sędzią pierwszej instancji w sprawach o nieważność małżeństwa, których prawo wyraźnie nie wyłącza, jest biskup diecezjalny, który może wykonywać władzę sądowniczą osobiście

\footnotetext{
${ }^{18}$ „Aby postanowienia Soboru Watykańskiego II zostały ostatecznie zastosowane w praktyce w tak ważnej kwestii, postanowiono wyraźnie stwierdzić, że biskup osobiście w swoim Kościele, w którym jest ustanowiony pasterzem i głową, tym samym jest sędzią wobec wiernych, którzy zostali mu powierzeni”, Papież Franciszek, dz. cyt., s. 11.

${ }^{19}$ Papież Franciszek, dz. cyt., s. 13.

20 Tamże, s. 11-13.
} 
lub przez innych według przepisów prawa ${ }^{21}$. Biskup ma obowiązek ustanowienia dla swojej diecezji trybunału diecezjalnego dla spraw o nieważność małżeństwa (z zachowaniem uprawnienia tegoż biskupa do przyłączenia się do sąsiedniego trybunału diecezjalnego lub międzydiecezjalnego)222; niemniej jednak jeżeli w diecezji (lub sąsiednim trybunale wybranym zgodnie z przepisem kan. $1673 \$ 2$ ) nie ma możliwości ustanowienia trybunału kolegialnego, to w takim wypadku biskup diecezjalny winien powierzyć sprawy jednemu sędziemu będącemu duchownym ${ }^{23}$.

Ponadto, biskup winien przedstawić swoje wotum w sprawie dyspensy super rato ${ }^{24}$, wydać postanowienie - jako ordynariusz miejsca (zob. kan. $134 \$ 2$ ) - w przedmiocie zakazu (vetitum) zawierania nowego małżeństwa (nisi vetito ipsi sententiae apposito vel ab Ordinario loci statuto), po tym jak wyrok stwierdzający nieważność małżeństwa stał się wykonalny ${ }^{25}$, oraz zatroszczyć się - jako ordynariusz miejsca „by w księgach małżeństw i ochrzczonych jak najszybciej dokonano adnotacji o orzeczonej nieważności małżeństwa oraz ustanowionych ewentualnie zakazach" 26 .

Jedynie do biskupa diecezjalnego (ipsi Episcopo dioecesano competit) należy orzekanie w sprawach o nieważność małżeństwa $\mathrm{w}$ procesie skróconym ${ }^{27}$; naturalnie przy spełnieniu jasno ustalonych przez prawo warunków. To znaczy „ilekroć: 1. żądanie zostało zgłoszone przez obydwoje małżonków lub przez jednego z nich za zgodą drugiego; 2. przytaczane są okoliczności dotyczące faktów lub osób, poparte zeznaniami lub dokumentami, które nie wymagają przeprowadzenia dokładniejszego badania albo dochodzenia oraz w sposób oczywisty wskazują na nieważnośćc" ${ }^{28}$. Warto jednocześnie

\footnotetext{
${ }^{21}$ Tamże, kan. $1673 \$ 1$.

${ }^{22}$ Tamże, kan. $1673 \$ 2$.

${ }^{23}$ Tamże, kan. $1673 \$ 4$.

${ }^{24}$ Tamże, kan. $1678 \$ 4$.

${ }^{25}$ Tamże, kan. $1682 \$ 1$.

${ }^{26}$ Tamże, kan. $1682 \$ 2$.

${ }^{27}$ Tamże, kan. 1683.

${ }^{28}$ Tamże.
} 
dodać, że w tym procesie biskup diecezjalny, jeżeli osiągnął moralną pewność co do nieważności małżeństwa, winien wydać wyrok; natomiast w przeciwnym razie przekazuje sprawę do procesu zwykłego ${ }^{29}$. Konkretnie oznacza to, że biskup wydaje tylko wyrok pozytywny ${ }^{30}$. Ponadto, biskup diecezjalny - zgodnie z wyraźnym zapisem nowego kan. 1688 - może orzec wyrokiem nieważność małżeństwa w procesie opartym na dokumentach ${ }^{31}$.

Jednocześnie „biskup, jako dobry Pasterz, powinien wyjść naprzeciw oczekiwaniom swoich wiernych, którzy potrzebują szczególnej opieki duszpasterskiej, dlatego wydaje się właściwym, aby wraz ze szczegółowymi przepisami stosowanymi w procesie małżeńskim, mając na względzie współpracę następcy Piotra z biskupami w rozpowszechnianiu znajomości prawa, przedstawić niektóre narzędzia, dzięki którym praca trybunałów mogłaby sprostać potrzebom wiernych, którzy proszą o ustalenie prawdy o istnieniu lub nieistnieniu węzła po rozpadzie ich małżeństwa" ${ }^{32}$.

Wśród wymienionych zasad, które wprost dotyczą obowiązków biskupa diecezjalnego trzeba wskazać troskę o małżonków będący w separacji i rozwiedzionych ${ }^{33}$, oraz zorganizowanie $-\mathrm{w}$ ramach jednolitego diecezjalnego duszpasterstwa małżeństw - duszpasterskiego badania przedprocesowego $\mathrm{w}$ ramach struktur parafialnych lub diecezjalnych dla wiernych będących w separacji oraz rozwiedzionych, poddających w wątpliwość ważność ich małżeństwa lub przekonanych o jego nieważności ${ }^{34}$. Powyższe badanie procesowe zostało integralnie związane $\mathrm{z}$ utworzeniem specjalnej stałej struktury dla wskazanej posługi oraz złączone z ewentualnym sporządzenie vademecum dla badania przedprocesowego ${ }^{35}$. Powyższe dochodzenie

\footnotetext{
${ }^{29}$ Tamże, kan. $1687 \S 1$.

${ }^{30}$ Zob. Zasady proceduralne w sprawach o stwierdzenie nieważności małżeństwa, w: Papież Franciszek, dz. cyt., art. 19-20.

${ }^{31}$ Zob. Tamże, art. 21.

${ }^{32}$ Tamże, s. 35.

${ }^{33}$ Tamże, art. 1.

34 Tamże, art. 2.

${ }^{35}$ Tamże.
} 
kończy się ewentualnym sporządzeniem skargi powodowej celem złożenia jej we właściwym trybunale ${ }^{36}$.

M.p. „Mitis Iudex Dominus Iesus” konkretnymi dyspozycjami sprawia, że przed biskupem diecezjalnym powstało nowe, szczególne, osobiste pole odpowiedzialności, gdyż jest on teraz odpowiedzialnym nie tylko za stworzenie w powierzonym Kościele partykularnym kompetentnych struktur sądowych oraz za ich sprawne działanie, ale jego posługa $\mathrm{w}$ analizowanym aspekcie władzy ma być o wiele dynamiczniejsza. Nowością jest to, że tylko i wyłącznie w jego kompetencji pozostaje mianowanie osób świeckich na urząd sędziego kościelnego (zob. kan. $1673 \$ 3$ ) oraz ewentualne powoływanie trybunałów jednoosobowych (zob. kan. $1673 \$ 4$ ); ponadto ma on stworzyć nowe oraz kompetentne duszpasterskie struktury przedprocesowe, natomiast sam będąc sędzią ma być przykładem oraz stałym punktem odniesienia dla funkcjonowania sądownictwa w powierzonym mu Kościele partykularnym. A zatem biskup diecezjalny będzie teraz postrzegany nie tylko jako pastor bonus ale jednocześnie jako iustus iudex ${ }^{37}$. Wydaje się ponadto, że ten konkretny aspekt posługi biskupa będzie dodatkowo weryfikowany przez różne osoby, w szczególności należałoby tutaj wymienić adwokatów kościelnych, z których fachowej pomocy pragnie korzystać coraz więcej osób ${ }^{38}$.

Dodatkowo należy pamiętać, że biskup został praktycznie zobowiązany do pogłębiania swojej wiedzy w zakresie materialnego prawa małżeńskiego i formalnego prawa procesowego. A zatem mówiąc bardzo konkretnie, dzisiaj biskup nie może „udawać” - w szczególności wobec swoich współpracowników - że się zna na prawie kanonicznym, on musi posiadać jasną i konkretną wiedzę, praktycznie przydatną przede wszystkim do wyrokowania.

\footnotetext{
${ }^{36}$ Tamże, art. 5.

${ }^{37}$ Zob. R. Sobański, Iudex veritatem de matrimonio dicit, Ius Matrimoniale 4 (1999), s. 181-196.

${ }^{38}$ Zob. F. Ferone, I doveri e i diritti dell'avvocato dopo il motu proprio Mitis Iudex Dominus Iesus, Romae 2021.
} 
Papież Franciszek w swojej reformie procesowej, w aspekcie przyspieszenia oraz uproszczenia orzekania nieważności małżeństwa, między innymi, konkretnie postanowił, aby „nie były już wymagane dwa zgodne wyroki stwierdzające nieważność małżeństwa, ale wystarczała moralna pewność osiągnięta przez pierwszego sędziego zgodnie z przepisami prawa"39. Jest to bardzo wyraźne odejście od wielowiekowej praktyki Kościoła w materii orzekania nieważności małżeństwa, konkretnie od decyzji papieża Benedykta XIV zawartej w konstytucji apostolskiej „Dei miseratione” z 3 listopada 1741 roku; co ciekawe w niedalekiej przeszłości propozycje zniesienia obowiązku dwóch zgodnych wyroków w procesie małżeńskim nie zostały zaakceptowane, ani podczas prac nad posoborowym Kodeksem prawa kanonicznego, ani podczas sukcesywnej redakcji instrukcji procesowej „Dignitas connubii” z 2005 roku $^{40}$. Aktualne przyspieszenie orzekania nieważności małżeństwa nie może jednak zagubić prawdy na temat zaskarżonego małżeństwa ${ }^{41}$. Każdy bowiem wyrok sędziego kościelnego musi opierać się na pewności moralnej, która jest fundamentem każdego sprawiedliwego wyroku, jak to było i jest podkreślane w magisterium Biskupów Rzymskich ${ }^{42}$.

\section{Wybrane praktyczne uwagi do "procesu biskupiego"}

Zreformowane kanony procesowe w przedmiocie orzeczenia przez sąd Kościoła nieważności małżeństwa nakładają na wikariusza

\footnotetext{
${ }^{39}$ Papież Franciszek, dz. cyt., s. 11. Zob. T. Rozkrut, Czy drugi wyrok w procesie małżeńskim jest konieczny?, Roczniki Nauk Prawnych 2 (2016), s. 137-153.

${ }^{40}$ J. Llobell, I processi matrimoniali nella Chiesa, Roma 2015, s. 240. Zob. J. LloBELL, La pastoralità del complesso processo canonico matrimoniale: suggerimenti per renderlo più facile e tempestivo, w: VII. Ogólnopolskie Forum Sądowe: Kanoniczny proces małżeński dziesięć lat po opublikowaniu „Dignitas connubii”. Materiały z ogólnopolskiego spotkania pracowników sądownictwa kościelnego w Gródku nad Dunajcem w dniach 8-9 czerwca 2015 roku, T. Rozkrut (red.), Tarnów 2016, s. 17-52.

${ }^{41}$ F. Coccopalmerio, dz. cyt., s. 22.

${ }^{42}$ C.J. Errázuriz M., Corso fondamentale sul diritto nella Chiesa, Milano 2017, s. $520 \mathrm{n}$.
} 
sądowego nowe obowiązki oraz kompetencje; z czym także związana jest jego dodatkowa odpowiedzialność wynikająca z pełnionego urzędu ${ }^{43}$. Przede wszystkim to teraz on personalnie decyduje najpierw o przyjęciu skargi powodowej - „po otrzymaniu skargi powodowej wikariusz sądowy, jeżeli uważa, że posiada ona jakieś podstawy, winien ją przyjąć” (kan. $1676 \$ 1^{44}$ ), oraz sukcesywnie określa formułę wątpliwości oraz rodzaj procesu małżeńskiego - „winien swoim dekretem określić formułę wątpliwości oraz zdecydować, czy sprawa ma być rozpatrywana w procesie zwykłym, czy w procesie skróconym, według kan. 1683-1687” (kan. $1676 \S 2)^{45}$.

Musi on jednocześnie pamiętać, że zgodnie z kan. $1505 \$ 1$, „powinien swoim dekretem jak najszybciej skargę albo przyjąć, albo odrzucić". Ewentualny uzasadniony rekurs przeciwko odrzuceniu skargi powodowej należałoby wnieść do sądu apelacyjnego w ciągu dziesięciu użytecznych dni. Może on także dotyczyć nieskierowania sprawy na drogę procesu skróconego, przy założeniu, że spełnione są dla takiego procesu warunki ustalone przez znowelizowane prawo procesowe $^{46}$.

W wypadku kierowania sprawy na drogę procesu skróconego, wikariusz sądowy - zgodnie z zaleceniem Subsydium aplikacyjnego Trybunału Roty Rzymskiej - winien uwzględnić kryteria biskupa diecezjalnego wydane w tym celu ${ }^{47}$. Naturalnie brak dyspozycyjności biskupa do angażowania się w proces skrócony nie może być podstawą

${ }^{43}$ Zob. T. Rozkrut, Wybrane oraz praktyczne uwagi odnoszace się do zreformowanego przez papieża Franciszka procesu dotyczacego orzeczenia nieważności matżeństwa (w szczególności w przedmiocie procesu biskupiego), w: VIII. Ogólnopolskie Forum Sądowe: Reforma procesowa papieża Franciszka - pierwsze doświadczenie. Materiały z ogólnopolskiego spotkania pracowników sądownictwa kościelnego w Gródku nad Dunajcem w dniach 12-13 czerwca 2017 roku, red. T. Rozkrut, Tarnów 2018, s. 179-192.

${ }^{44}$ Zob. MIDI, kan. 1675.

${ }^{45}$ Zob. G.P. Montini, L'accordo dei coniugi quale presupposto del processus matrimonialis brevior (can. 1683, $1^{\circ}$ MIDI), Periodica 105 (2016), s. 395-415.

${ }^{46} \mathrm{KPK}$, kan. $1505 \$ 4$.

${ }^{47}$ Tribunale Apostolico della Rota Romana, dz. cyt., s. 38. 
skierowania sprawy na drogę procesu zwykłego. Aktualnie - zgodnie z wyraźną wolą papieża Franciszka, najwyższego prawodawcy w Kościele - biskup ma obowiązek sprawować w powierzonym mu Kościele partykularnym władzę sądowniczą i nie może w żaden sposób dyspensować się od tego obowiązku.

Niewątpliwie wskazany dekret oficjała powinien być należycie umotywowany, przede wszystkim w przedmiocie wyboru formy procesu. Wikariusz sądowy winien także pamiętać, że może on także zachęcić stronę pozwaną do rozważenia czy nie przyłączyć się do prośby strony powodowej, ewentualnie uzupełnić skargę powodową nowymi elementami oraz swoim podpisem, celem skierowania jej na drogę proces skróconego ${ }^{48}$. Ten nowy, dynamiczny aspekt procesowej funkcji oficjała, nie może dokonać się na zasadzie uzyskania zgody strony pozwanej na proces skrócony w czasie rozmowy telefonicznej; rozmowa winna odbyć się w siedzibie sądu kościelnego, tak aby był odpowiedni czas na rozwagę oraz przemyślenie decyzji.

Nowe kompetencje, przyznane przez reformę procesową dokonaną przez papieża Franciszka wikariuszowi sądowemu, niewątpliwie wymagają od niego rzetelnej oraz gruntownej wiedzy, roztropności, rozwagi oraz właściwego doświadczenia i praktyki sądowej; stąd też już w instrukcji procesowej z 2005 roku „Dignitas connubii” Stolica Apostolska - przy zachowaniu kodeksowych wymogów przy mianowaniu na urząd oficjała (kan. $1420 \$ 4$ ) - jasno postulowała w art. $42 \S 2$ : „gorąco zaleca się, aby nikt, kto nie posiada doświadczenia sądowego, nie był mianowany na wikariusza sądowego lub pomocniczego wikariusza sądowego".

Mając na uwadze normę kan. $87 \$ 1$, która stanowi, że biskup diecezjalny nie może dyspensować od ustaw procesowych, należy pamiętać, że nie może zrodzić się praktyka sądowa, która różniłaby się, od wskazanego przez nowe kanony z 2015 roku powszechnego iter procesowego; czyli mówiąc konkretnie nie można robić procesu małżeńskiego „po swojemu”, co w szczególności dotyczyłoby

${ }^{48}$ A. Zambon, Il motu proprio Mitis Iudex. Punto di vista di un giudice, Periodica 105 (2016), s. 430. 
procesu biskupiego; nie oznacza to jednak, że biskup diecezjalny został w ten sposób automatycznie pozbawiony twórczej kreatywności oraz dynamiczności w czuwaniu nad pracą sądu kościelnego oraz w szczególności nad etapem przedprocesowym w kanonicznym procesie małżeńskim ${ }^{49}$. Ponadto, nic nie stoi na przeszkodzie, aby biskup, który otrzymał już akta procesowe, oprócz obowiązkowej konsultacji z instruktorem oraz asesorem, spotkał się także z obrońca węzła małżeńskiego, adwokatem stron, czy też ewentualnie poprosił o dodatkowe specjalistyczne wyjaśnienia biegłego sądowego.

$\mathrm{W}$ procesie biskupim mają być bardzo wiernie zachowane wszystkie elementy wyznaczone przez znowelizowane prawo procesowe, aby nie doszło do takiej sytuacji, że nieprawidłowe zastosowanie tej nowej formy orzekania nieważności małżeństwa (w której wydawany jest tylko wyrok pozytywny ${ }^{50}$ ), mogłoby utożsamić powyższy proces z tzw. „zdjęciem błogosławieństwa” przez biskupa, które ma miejsce w Kościele prawosławnym ${ }^{51}$, albo też nawet z rozwodem cywilnym (na zasadzie zgodności konsensualnej stron procesowych) i jednocześnie usprawiedliwiałoby niepoprawne stosowanie, dość popularnego zwrotu „rozwód kościelny”, na określenie kanonicznego orzeczenia nieważności małżeństwa. Dlatego też wymagana jest tutaj należna czujność oraz roztropność, np. proces biskupi, w szczególności posiedzenie celem zebrania dowodów procesowych o którym czytamy w nowym kan. 1686, nie może być przeprowadzone na zasadzie tzw. „okrągłego stołu”, przy którym zbierają się wspólnie strony procesowe, ich adwokaci, świadkowie stron, instruktor, asesor oraz obrońca węzła małżeńskiego, aby wspólnie „podyskutować” na temat zaskarżonego małżeństwa. Konsekwencją nieprawidłowego zastosowania norm regulujących proces małżeński skrócony przed biskupem winno

${ }^{49}$ Zob. M.J. Arroba Conde, Le "Litterae motu proprio datae" sulla riforma dei Processi di nullità matrimoniale: prima analisi. Alcuni aspetti delle nuove norme sulle cause di nullità del matrimonio, Apollinaris 87 (2015), s. 560.

${ }^{50}$ MIDI, kan. $1687 \S 1$.

${ }^{51}$ Zob. U. Now ICKA, Stwierdzenie stanu wolnego wiernych prawosławnych na forum Kościoła Katolickiego, Warszawa 2012, s. 129-172. 
być złożenie skargi o nieważność takiego postępowania procesowego; w szczególności powinien to uczynić obrońca węzła małżeńskiego ${ }^{52}$.

Ponadto, należałoby podkreślić, że wspomniane posiedzenie winno zostać dobrze zaprogramowane oraz przygotowane (trzeba między innymi zwrócić uwagę na stawiane pytania, bowiem wspomniane posiedzenie zasadniczo nie będzie więcej powtarzane celem uzupełnienia dowodów procesowych), właśnie w perspektywie zebrania jak najbardziej wartościowego materiału dowodowego, który zdecyduje o dalszych losach procesu. Nie ulega wątpliwości, że sprawa sądowa rozstrzyga się właśnie poprzez jak najlepsze zgromadzenie materiału dowodowego.

Przewidziana przez nowy kan. 1685 obecność wielu osób na posiedzeniu w procesie biskupim będzie wymagała od instruktora swoistego kunsztu, celem uniknięcia niezręcznych sytuacji lub nawet awantury między obecnymi jednocześnie wieloma osobami ${ }^{53}$. Niewątpliwie warto w tym miejscu przywołać kanon na temat konfrontacji stron procesowych, który najpierw postanawia, że „świadkowie powinni być przesłuchani osobno”, oraz sukcesywnie: „jeśli świadkowie nie zgadzają się, między sobą lub ze stroną, w rzeczy poważnej, sędzia może zgromadzić i skonfrontować różniących się między sobą, tak by uniknąć, o ile to możliwe, kłótni i zgorszenia" 54 .

Stąd też na instruktora w procesie biskupim, wikariusz sądowy, powinien wyznaczyć doświadczonego sędziego kościelnego, który znając dobrze kanoniczne materialne prawo małżeńskie oraz ciesząc się odpowiednią praktyką sądową oraz powiązanym z tym faktem odpowiednim autorytetem w lokalnym środowisku, będzie w stanie sprawnie wydobyć prawdę na temat zaskarżonego małżeństwa, przede wszystkim, poprzez zebranie odpowiedniego i przekonywującego materiału dowodowego.

Konkretnie, powołany instruktor, musi wiedział o co pytać, czyli jak mądrze, syntetycznie, a przede wszystkim merytorycznie,

\footnotetext{
${ }^{52}$ G.P. Montini, L'uso illegittimo del processus brevior ..., dz. cyt., s. 37n.

${ }^{53}$ Zob. MIDI, kan. 1677.

${ }^{54}$ KPK, kan. $1560 \$ 1-2$.
} 
przeprowadzić krótką instrukcję dowodową, mając na uwadze to, że biskup diecezjalny sukcesywnie - w wypadku wątpliwości, co do osiągnięcia pewności moralnej w przedmiocie nieważności zaskarżonego małżeństwa - skieruje sprawę do jej rozpatrzenia na drodze procesu zwykłego ${ }^{55}$. Mówiąc syntetycznie, winien on - instruktor posiadać należne przygotowanie doktrynalne oraz praktyczne ${ }^{56}$.

W sytuacji gdy np. biskup diecezjalny stwierdzi, że nie osiągnął wymaganej przez prawo procesowe pewności moralnej i skieruje sprawę do rozpatrzenia na drodze procesu zwykłego, to niewątpliwie taki fakt wzbudzi zdziwienie, a może nawet rozgoryczenie, stron procesowych; tym bardziej, że rozpoczęty „proces biskupi” - poprzez swoją strukturę - nastawiony jest na wyrok pozytywny. Wydaje się, że jeszcze większe zdziwienie - co do funkcjonowania sądownictwa Kościoła - będą miały strony procesowe, gdy po sukcesywnie przeprowadzonym procesie zwykłym zostanie wydany wyrok pozytywny. Naturalnie taki proces będzie się toczył zgodnie z przyznanym wcześniej numerem procesowym, natomiast oficjał będzie musiał podjąć czynności związane $\mathrm{z}$ iter procesu zwykłego, w szczególności będzie musiał powołać trybunał kolegialny, zgodnie z nowym kan. $1676 \$ 3$.

A zatem, gdyby rozpatrywana sprawa wymagała pogłębionej oraz wielowątkowej instrukcji dowodowej, w tym specjalistycznej opinii biegłego na bazie materiału dowodowego oraz badania czy też rozmowy ze stronami procesowymi, to sprawę od początku należałoby skierować na drogę procesu zwykłego. Natomiast jeżeli zgromadzony materiał dowodowy zawierałby już specjalistyczne badania medyczne (w tym np. psychiatryczne) czy też opinie psychologiczne, to w takim wypadku na asesora w procesie biskupim można by powołać biegłego sądu kościelnego, aby w sposób kompetentny wyjaśnił - w szczególności biskupowi diecezjalnemu (ale także wspomógł merytorycznie

\footnotetext{
${ }^{55}$ MIDI, kan. $1687 \S 1$.

${ }^{56}$ Zob. J.G. Martín, Alcune considerazioni sui concetti «istruttore» e «uditore»e sull'espresione «giudice istruttore», Revista Española de Derecho Canónico 73 (2016), s. 181-206.
} 
uwagami oraz sugestiami samego instruktora) - znaczenie dowodowe przedłożonej dokumentacji.

Jak zatem widać, proces małżeński skrócony przed biskupem diecezjalnym, nie jest w cale taki łatwy, jakby mógł się wydawać na pierwszy rzut oka; wymaga on dużej wiedzy oraz odpowiedniego przygotowania wynikającego z praktyki sądowej. Niewątpliwie duże znaczenie będzie tutaj odgrywać także dobre przedprocesowe przygotowanie procesu skróconego przed biskupem ${ }^{57}$.

Publikacja akt nie jest wymagana w procesie skróconym ale może ona mieć miejsce, przede wszystkim, aby jeszcze lepiej zabezpieczyć stronom procesowym prawo do obrony. Nie musi ona mieć charakteru formalnego, ale jeżeli strony (lub ich adwokaci) poproszą o udostępnienie im akt procesowych, to nie należy się z tym faktem opóźniać i dać im możliwość do zapoznania się ze zgromadzonym materiałem dowodowym lub jego częścią. Nowy kan. $1687 \$ 1$ stanowi jasno, że „po otrzymaniu akt biskup diecezjalny, po konsultacji $z$ instruktorem oraz asesorem, rozważywszy uwagi obrońcy węzła małżeńskiego i wnioski obrończe stron, gdy takie zgłoszono, jeżeli osiągnął moralną pewność co do nieważności małżeństwa, winien wydać wyrok. W przeciwnym razie przekazuje sprawę do procesu zwykłego".

Jak wskazuje M.J. Aroba Conde w analizowanie sprawy oraz w podjęciu decyzji biskup diecezjalny, któremu zazwyczaj brak doświadczenia sądowego, ma obowiązek przeprowadzić konsultację $\mathrm{z}$ instruktorem oraz asesorem, która wynika z normy kan. $127 \S 2$, n. 2, gdzie czytamy: „gdy ustawa postanawia, że przełożony do podjęcia pewnych aktów potrzebuje zgody lub rady niektórych pojedynczych osób, wtedy: jeżeli jest wymagana rada, nieważny jest akt przełożonego bez wysłuchania zdania tych osób. Wprawdzie przełożony nie ma żadnego obowiązku pójść za ich zdaniem, chociażby było zgodne, jednakże bez przeważającego powodu - przez siebie ocenianego - nie

${ }^{57}$ Zob. C.-M. FABR Is, Indagine pregiudiziale o indagine pastorale nel motu proprio Mitis Iudex Dominus Iesus. Novità normative e profili problematici, Ius Ecclesiae, 28 (2016), s. 479-504. 
powinien odstępować od wyrażonego przez nich zdania, zwłaszcza gdy jest zgodne" 58 . A zatem brak powyższej konsultacji z asesorem ora instruktorem, tak w wypadku wydania wyroku pozytywnego czy też w wypadku skierowania sprawy na drogę procesu zwykłego, sprawia, że będziemy mieli do czynienie z nieważnym aktem biskupa; co więcej cytowany procesualista proponuje, aby w aktach procesowych (czy też w samym uzasadnieniu wydanego wyroku) zostawić informację o odbyciu się wspomnianej konsultacji ${ }^{59}$.

Powyższa konsultacja, zwołana przez biskupa diecezjalnego, może odbyć się w rozmaity sposób, np. może mieć miejsce wspólne spotkanie $\mathrm{z}$ instruktorem oraz $\mathrm{z}$ asesorem, może ona, w zależności od potrzeb, mieć miejsce jeden raz lub więcej, ponadto biskup diecezjalny może na konsultację wymienione osoby wzywać pojedynczo ${ }^{60}$. Mogą oni swoje opinie, czy też uwagi, przedstawić na piśmie, ale nigdy nie mogą przekroczyć swoich kompetencji, a zatem nie mogą wypowiadać się na temat nieważności zaskarżonego małżeństwa, gdyż jest to wyłączna kompetencja biskupa diecezjalnego, który w tym wypadku jest jedynym sędzią in casu.

\section{Dynamiczny aspekt „procesu biskupiego"}

Analizowany sposób orzekania nieważności małżeństwa, interpretowałbym również i w tym sensie, że gdyby biskup diecezjalny orzekający w procesie skróconym, po analizie otrzymanego materiału dowodowego oraz przeprowadzonej konsultacji z instruktorem oraz asesorem zgodnie z nowym kan. kan. $1687 \$ 1$, mając np. wcześniejsze osobiste doświadczenia $\mathrm{z}$ prowadzonych procesów małżeńskich, a nie mając jeszcze pewności moralnej i nie chcąc orzekać pozytywnie na zasadzie prawdopodobieństwa, a jednocześnie widząc „światełko w tunelu” dla pozytywnego wyroku, powinien zaproponować „in

\footnotetext{
${ }^{58}$ M.J. Arroba Conde, Il processo piu breve davanti al vescovo, w: Pastorale giudiziaria e prassi processuale nelle cause di nullità del matrimonio, red. M.J. A. Conde i C. Izzi, Milano 2017, s. 158.

${ }^{59}$ Tamże, przypis nr 76.

${ }^{60}$ W. GóRALSKI, Proces małżeński skrócony przed biskupem, Płock 2017, s. 151.
} 
casu" poszerzenie, czy też uzupełnienie, zebranego już materiału dowodowego, aby sprawa nie była kierowana na drogę procesu zwykłego, co wiązałoby się niewątpliwie z sukcesywnym wydłużeniem postępowania procesowego. $\mathrm{W}$ takim wypadku zaproponowane uzupełnienie byłoby po to, aby mógł on sam nabrać koniecznego kanonicznego przekonania celem wydania wyroku ${ }^{61}$. Naturalnie zaproponowany sposób postępowania biskupa należałoby traktować jako wyjątkowy; przestrzega on jednocześnie, aby w sposób nieodpowiedzialny nie kierować spraw na wskazany sposób orzekania oraz wzywa, aby przepisany sposób orzekania był wiernie przestrzegany, a zebrany materiał dowodowy jak najbardziej kompletny.

Widzimy zatem jak wielkie znaczenie, nie tylko do ważności procesu małżeńskiego skróconego przed biskupem, ale także praktyczne, ma spotkanie biskupa diecezjalnego $\mathrm{z}$ instruktorem oraz asesorem, również $\mathrm{w}$ aspekcie ewentualnego uzupełnienia zgromadzonego materiału dowodowego.

Dlatego też, nie ulega wątpliwości, że w procesie skróconym wikariusz sądowy, co już wcześniej zostało podkreślone, na instruktora powinien wyznaczyć kompetentnego oraz doświadczonego sędziego, gdyż jest to proces niełatwy, który jest związany z dużą odpowiedzialnością, tak na poziomie zbierania dowodów, jak i ich sukcesywnej oceny oraz podjęcia decyzji przez orzekającego biskupa diecezjalnego, tym bardziej, że ta forma procesu nie przewiduje formalnej publikacji zgromadzonego materiału dowodowego ${ }^{62}$. Czytamy w nowym prawie procesowym następująco: „Po otrzymaniu akt biskup diecezjalny, po konsultacji z instruktorem oraz asesorem, rozważywszy uwagi obrońcy węzła i wnioski obrończe stron, gdy takie zgłoszono, jeżeli osiągnął moralną pewność co do nieważności małżeństwa

${ }^{61}$ Zob. T. Rozkrut, Dynamiczna (aktywna) rola sędziego w kanonicznym procesie małżeńskim, w: IX. Ogólnopolskie Forum Sądowe. Małżeństwo i jego nieważność a współczesne sądownictwo Kościoła. Materiały z ogólnopolskiego spotkania pracowników sądownictwa kościelnego w Gródku nad Dunajcem w dniach 10-11 czerwca 2019 roku, red. T. Rozkrut, Tarnów 2020, s. 121-134.

${ }^{62}$ Zob. MIDI, kan. 1685. 
winien wydać wyrok"63. Stąd też Kongregacja Wychowania Katolickiego bardzo jasno wymaga od biskupa należytego specjalistycznego przygotowania: „wykonywanie urzędu sędziego w processus brevior wymaga od biskupa diecezjalnego rzeczywistej znajomości materialnego prawa małżeńskiego oraz procesowego" ${ }^{64}$. Natomiast papież Franciszek jasno wskazał: „Nie umknęło jednak mojej uwadze, jak bardzo postępowanie skrócone może zagrozić zasadzie nierozerwalności małżeństwa. Właśnie $\mathrm{z}$ tego powodu postanawiam, aby w takim procesie sędzią był ustanowiony osobiście biskup, który mocą swego zadania pasterskiego daje największą gwarancję katolickiej jedności z Piotrem w wierze i dyscyplinie" 65 .

Z kolei Jan Paweł II w przemówieniu rotalnym z roku 1996 wskazał, że każdy proces małżeński wymaga właściwego zaangażowania w dokonywanej ocenie procesowej, która uwzględnia indywidualność podmiotu oraz specyfikę kultury, w której on wzrastał i żyje aktualnie. Niepowtarzalność bowiem, która dotyczy każdego człowieka, sprawia, że nie może on być postrzegany abstrakcyjnie, ale musi być widziany jako podmiot zanurzony w rzeczywistość historyczną, etniczną, społeczną, a przede wszystkim kulturową, która go charakteryzuje w jego pojedynczości. Równocześnie w ten sposób zostaje potwierdzona fundamentalna i nieusuwalna zasada nienaruszalności prawa Bożego, tak naturalnego jak i pozytywnego, autentycznie formułowana przez normy kanoniczne na temat specyficznych materii ${ }^{66}$.

\section{Zakończenie}

Poprawne zastosowanie „procesu biskupiego” w orzeczeniu nieważności małżeństwa winno przyczynić się nie tylko dla rozwiązania konkretnych problemów sumienia, co niewątpliwie jest jego ważnym celem, ale także może posłużyć ukazaniu Kościoła jako sprawnej instytucji, a tym samym może przyczynić się do podniesienia jego

\footnotetext{
${ }^{63}$ MIDI, kan. $1687 \S 1$.

${ }^{64}$ Kongregacja Edukacji Katolickiej (Instytucji Studiów Wyższych), dz. cyt., s. 4.

${ }^{65}$ Papież Franciszek, dz. cyt., s. 13.

${ }^{66}$ T. Rozkrut, Jan Paweł II do Roty Rzymskiej, Tarnów 2003, s. 177.
} 
prestiżu oraz autorytetu w dzisiejszym czasie. Niewątpliwie w tej perspektywie należy postrzegać zasygnalizowane nieprawidłowości, które pojawiły się w partykularnych interpretacjach, niezgodnych $z$ duchem oraz literą reformy procesowej papieża Franciszka. Ważną rzeczą jest, aby powstałe błędy umiejętnie korygować i naprawiać, tym bardziej, że mamy do czynienia z procesem kościelnym, w którym centralną postacią jest biskup. Stąd też papież Franciszek, poprzez swoje dynamiczne magisterium, także w przedmiocie processus brevior, pragnie przyczyniać się do tego, aby proces ten był należycie rozumiany oraz stosowany ${ }^{67}$.

Ważnym zagadnieniem, na który zwraca uwagę praktyczny pontyfikat papieża Franciszka, jest niewątpliwie osobista odpowiedzialność za podejmowane decyzje w Kościele, która w szczególności dotyczy jego autorytetów. Bowiem, także w Kościele osoby popełniają błędy, za które ponoszą odpowiedzialność i winny za nie odpowiadać; ich precyzyjne określenie i sukcesywne naprawienie sprawi, że Kościół będzie instytucją wiarygodną we współczesnym świecie ${ }^{68}$. Ponadto, w ten sposób będzie także kształtował sumienia wiernych oraz należycie wypełniał otrzymaną misję ${ }^{69}$.

\section{Correct use of the "Bishop's process" in adjudicating nullity of marriage}

A few years have passed since Pope Francis amended the method of adjudicating nullity of marriage by the Church courts in 2015. The time that passed, especially the experience gained during the time, encourages one to raise a question on the correctness of usage of the amendment introduced in the process law that is, unarguably, bold. In particular, the question should relate to the "abbreviated process" that, due to its specificity, can

${ }^{67}$ Zob. M. Del Pozzo, Chiarimenti pontifici sul "processus brevior”. Riflessioni alla luce del Discorso del 25 novembre 2017, Ius canonicum 58 (2018), s. 503-537.

${ }^{68}$ E. BAura I F. Puig, Presentazione, w: La responsabilità giuridica degli enti ecclesiastici, red. E. Baura i F. Puig, Milano 2020, s. IX.

${ }^{69}$ Zob. E. ZANetTi (red.), Coscienza e cause di nullità matrimoniale. Riflessioni di fondo e proposte operative, Milano 2020. 
also be called the "Bishop's process". An important moment to take up the topic of the correct usage of the abbreviated process before a bishop is an article published by G.P. Montini that pertains to unlawful use of processus brevior (G.P. Montini, L'uso illegittimo del processus brevior. Rimedi processuali ordinari e straordinari, Periodica 108 (2019) 35-72). The Pope Francis' reform has clearly determined that the requisite of evident nullity of marriage is essential not only at the beginning of the process, but it must be present in the course of the entire evidentiary proceedings that is to result in a positive judgement, so that an accusation that the processus brevior is conducted illegally cannot be made. Selected elements picked out from the court practice suggest that things that are the most essential for the analysed method of adjudication of the marriage nullity by the authority of the Church must be reminded in a synthetic manner. Therefore, the following problematic aspects have been singled out: selected assumptions of the Pope Francis' process reform of 2015, process tasks and obligations of a diocesan bishop, selected practical remarks relating to the "Bishop's process".

A correct use of the "Bishop's process" in adjudicating nullity of marriage should not only contribute to solving specific issues of conscience, which without any doubts constitutes its important purpose, but can also be used to present the Church as a proficient institution. Thereby, it can contribute to raising the Church's prestige and authority in the present world. Undoubtedly, the signalled abnormalities that appeared in particular interpretations that are discordant with the Pope Francis process reform's spirit and the letter of the reform must be seen from this perspective. It is important that the errors are skilfully corrected and fixed. This is the more important that this is the Church proceedings, the central figure of which is bishop. An important issue, to which the Pope Francis' practical pontiff draws attention is, unarguably, personal responsibility for decisions made in the Church, which specifically relates to the authorities of the Church. For people in the Church also make errors, for which they bear responsibility and should face their consequences. Their precise specification and successive remediation will make the Church a trustworthy institution in the present world. Furthermore, this will allow it to shape consciences of the faithful and fulfil the received mission in an appropriate manner. 
SŁowA KLUCzowe: małżeństwo; odpowiedzialność; papież Franciszek; proces skrócony; reforma procesowa; wierność prawu

KEYwORDs: marriage; responsibility; Pope Francis; abbreviated process; process reform; fidelity to law

\section{Nota O AUTORzE}

Ks. PROF. DR HAB. TOMASz ROZKRUT - profesor nauk prawnych; dziekan Wydziału Prawa Kanonicznego UPJPII w Krakowie w latach 2014-2020, od 1 września 2020 prorektor UPJPII w Krakowie. Od 2006 r. konsultor Rady Prawnej Konferencji Episkopatu Polski. Autor publikacji głównie z prawa dotyczącego organizacji Kościoła oraz kościelnego prawa procesowego. Organizator cyklicznych sympozjum naukowych dotyczących kanonicznego materialnego prawa małżeńskiego oraz kościelnego prawa procesowego w Gródku nad Dunajcem („Ogólnopolskie Forum Sądowe”: 2004, 2005, 2007, 2009, 2011, 2013, 2015, 2017, 2019). 